\title{
Venovenous anastomosis in macular telangiectasia type 2: an unusual presentation
}

\author{
Avadhesh Oli, Raja Narayanan 다
}

Department of Retina, LV Prasad Eye Institute, Hyderabad, India

\section{Correspondence to} Dr Raja Narayanan; narayanan@lvpei.org

Accepted 30 May 2020

\section{DESCRIPTION}

A 55-year-old woman presented with reduced vision in both eyes (BE). Her visual acuity was 20/100 in the right eye (RE) and 20/320 in the left eye (LE). Anterior segment was normal except for early cataract. Fundus evaluation showed pigment alteration at the macula with subretinal neovascular membrane (SRNVM) and venovenous anastomosis of major veins around the fovea temporally in BE (figure 1A). Fundus fluorescein angiography (FFA) and indocyanine green confirmed SRNVM and venovenous anastomosis in BE (figure 1C-F; *).

Optical coherence tomography (OCT) in the RE showed posterior vitreous detachment and epiretinal membrane with intraretinal hyporeflective cystoid spaces, mild retinal thickening, hyperreflective dots in outer retina and disrupted subfoveal ellipsoid zone. In addition, OCT in the LE showed subretinal hyperreflective material. (figure 2A). Optical coherence tomography angiography (OCTA) en-face projection images showed the venovenous anastomosis (arrows figure 2B). OCTA also showed telangiectasia of parafoveal vessels in the deep capillary plexus.

The patient received intravitreal ranibizumab in BE. After 1 month, her vision improved to $20 / 60$ in the RE and remained stable in the LE. OCT showed reduced macular thickness.

MacTel type 2 is a neurodegenerative disorder involving Müller cells. It is characterised by parafoveal greying with crystalline deposits, pigment clumps and right-angled venules. ${ }^{12}$ SRNVM is a known complication of MacTel type 2 and is

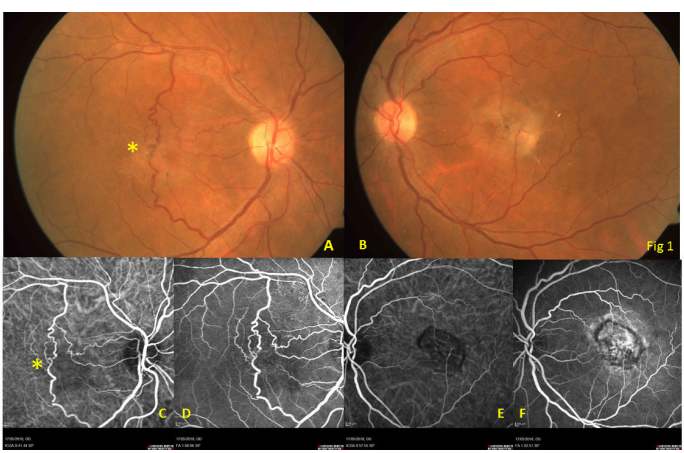

Figure 1 (A and B) Fundus evaluation showed pigment alteration at macula with subretinal neovascular membrane (SRNVM) and vascular anastomosis of major arcades veins around the fovea temporally in both eyes (BE). (C-F; *) Fundus fluorescein angiography and indocyanine green confirmed SRNVM and venovenous anastomosis in BE.
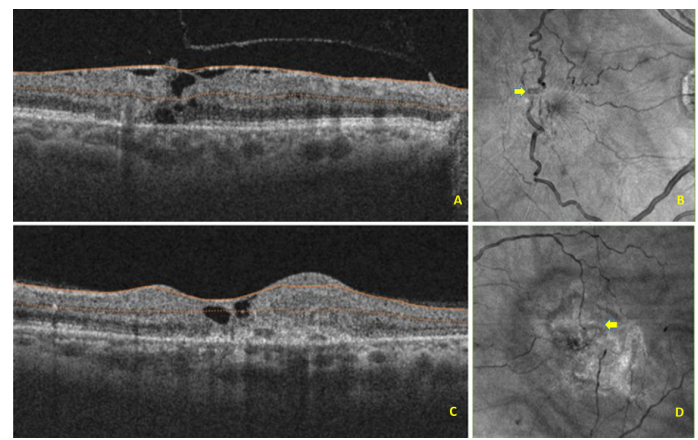

Figure 2 (A and C) The optical coherence tomography (OCT) in the right eye showed posterior vitreous detachment and epiretinal membrane with intraretinal hyporeflective cystoid spaces, mild retinal thickening, hyperreflective dots in outer retina and disrupted subfoveal ellipsoid zone. In addition, OCT in the left eye showed subretinal hyperreflective material. ( $\mathrm{B}$ and D) Optical coherence tomography angiography en-face projection images showed the venovenous anastomosis (yellow arrows).

estimated to occur in $10 \%$ of patients with this disease. $^{3}$

Venovenous anastomosis or collaterals of retinal vessels is a rare entity, commonly associated with retinal venous occlusion. ${ }^{4}$

In this patient, anastomosis of main arcade vessels is a novel finding in the setting of MacTel, which alerted us to carefully look for any vascular changes. On carefully reviewing the FFA images, flow restriction in superior vein was evident and probably, it was an old venous occlusion leading to formation of collaterals. The learning from this case was the fact that comorbidities do exist, and one needs to be clinically vigilant. This case also highlights the role of non-invasive en-face imaging in diagnosis of vascular anomalies.

\section{Learning points}

En-face scan on optical coherence tomography angiography is a useful non-invasive modality to view vascular anomalies.

- Novel finding of anastomosis of main arcade vessels gives a clue that comorbidities can occur, and that one needs to be clinically vigilant. 
Images in...

Contributors $\mathrm{AO}$ has collected the data and prepared the draft of the manuscript. RN has analysed the data and approved the final manuscript.

Funding The authors have not declared a specific grant for this research from any funding agency in the public, commercial or not-for-profit sectors.

Competing interests None declared.

Patient consent for publication Obtained.

Provenance and peer review Not commissioned; externally peer reviewed.

\section{ORCID iD}

Raja Narayanan http://orcid.org/0000-0001-9688-5859

\section{REFERENCES}

1 Wu L, Evans T, Arevalo JF. Idiopathic macular telangiectasia type 2 (idiopathic juxtafoveolar retinal telangiectasis type 2A, MAC TEL 2). Surv Ophthalmol 2013;58:536-59.

2 Tzaridis S, Heeren T, Mai C, et al. Right-angled vessels in macular telangiectasia type 2. Br J Ophthalmol 2019. doi:10.1136/bjophthalmol-2018-313364. [Epub ahead of print: 26 Feb 2019].

3 Heeren TFC, Chew EY, Clemons T, et al. Macular telangiectasia type 2 - Visual acuity, disease endstage and the MacTel Area. MacTel Project Report No. 8. Ophthalmology 2020.

4 Suzuki N, Hirano Y, Tomiyasu T, et al. Collateral vessels on optical coherence tomography angiography in eyes with branch retinal vein occlusion. Br J Ophthalmol 2019;103:1373-9.

Copyright 2020 BMJ Publishing Group. All rights reserved. For permission to reuse any of this content visit

https://www.bmj.com/company/products-services/rights-and-licensing/permissions/

BMJ Case Report Fellows may re-use this article for personal use and teaching without any further permission.

Become a Fellow of BMJ Case Reports today and you can:

- Submit as many cases as you like

- Enjoy fast sympathetic peer review and rapid publication of accepted articles

- Access all the published articles

Re-use any of the published material for personal use and teaching without further permission

\section{Customer Service}

If you have any further queries about your subscription, please contact our customer services team on +44 (0) 2071111105 or via email at support@bmj.com.

Visit casereports.bmj.com for more articles like this and to become a Fellow 